Jurnal BASTRA (Bahasa dan Sastra) : http://ojs.uho.ac.id/index.php/BASTRA

\title{
TINDAK TUTUR GURU DALAM PROSES BELAJAR-MENGAJAR \\ PADA TAMAN KANAK-KANAK WULELE SANGGULA DUA KELURAHAN KAMBU KOTA KENDARI
}

\section{OLEH}

\author{
Asmadania', La Ode Sidu Marafad ${ }^{2}$, dan Yunus ${ }^{3}$ \\ ${ }^{1}$ Alumni Jurusan Pend. Bahasa dan Sastra Indonesia, ${ }^{2,3}$ Dosen Jurusan Pendidikan \\ Bahasa dan Sastra Indonesia, Fakultas Keguruan dan Ilmu Pendidikan \\ Universitas Halu Oleo
}

\begin{abstract}
ABSTRAK
Masalah dalam penelitian ini adalah bagaimanakah jenis-jenis tindak tutur guru dalam proses belajar-mengajar di Taman Kanak-Kanak Wulele Sanggula Dua Kelurahan Kambu Kota Kendari?. Adapun tujuan yang ingin dicapai dalam penelitian ini adalah untuk mendeskripsikan jenis-jenis tindak tutur guru apa saja yang digunakan dalam proses belajar-mengajar pada Taman Kanak-Kanak Wulele Sanggula dua Kelurahan Kambu Kota Kendari. Metode yang digunakan dalam penelitian ini adalah metode deskriptif kualitatif. Hasil yang diproleh dalam penelitian ini berdasarkan tuturan guru dalam proses belajar-mengajar pada Taman Kanak-Kanak Wulele Sanggula Dua Kelurahan Kambu Kota Kendari yaitu kemampuan peserta didik anak usia 5-6 tahun dalam hal merespon tindak tutur gurunya masih belum merata, sebab masing-masing anak punya kemampuan sendiri dalam tingkatan merespon tuturan-tuturan gurunya.Hal tersebut dapat disimpulkan bahwa dari limma jenis tindak tutur berdasarkan hail analisis data yang terdapat pada TK Wulele Sanggula Dua Kelurahan Kambu Kota Kendari hanya empat jenis tindakan yang ada yaitu tindak representative, direktif, ekspresif dan komisif.
\end{abstract}

Kata Kunci: tindak, tutur, guru

106 | Jurnal BASTRA (Bahasa dan Sastra), Vol. 4 No.1, Edisi Januari 2019/e-ISSN: 2503-3875/

http://ojs.uho.ac.id/index.php/BASTRA 


\section{PENDAHULUAN}

\subsection{Latar Belakang}

Manusia sebagai makhluk sosial selalu berhubungan dengan orang lain. Dalam mengadakan hubungan atau interaksi dengan sesamanya, manusia memerlukan sebuah alat komunikasi. Alat komunikasi tersebut digunakan untuk menyampaikan ide, gagasan, atau pun pendapat. Alat komunikasi itu disebut bahasa.

Bahasa adalah suatu sistem lambang berupa bunyi yang bersifat arbitrer dan digunakan oleh suatu masyarakat tutur untuk bekerjasama, berkomunikasi dan mengidentifikasi diri. Sebagai sebuah sistem, maka bahasa terbentuk oleh suatu aturan, kaidah, atau pola-pola tertentu, baik dalam bidang tata bunyi, tata bentuk kata, maupun tata kalimat. Bila aturan, kaidah atau pola ini dilanggar maka komunikasi dapat terganggu (Sarnia, 2015: 1).

Penggunaan bahasa Indonesia dalam interaksi belajar-mengajar merupakan salah satu bentuk komunikasi. Melalui proses komunikasi akan memunculkan peristiwa tutur dan tindak tutur. Peristiwa tutur merupakan proses terjadinya atau berlangsungnya interaksi linguistik dalam suatu bentuk ujaran atau lebih yang melibatkan dua belah pihak, yaitu penutur dan lawan tutur dengan satu pokok tuturan di dalam waktu, tempat, dan situasi tertentu.Tindak tutur (istilah kridaklasana) 'pertuturan'/speech act, speech event): pengujaran kalimat untuk menyatakan agar suatu maksud dari pembicara diketahui pendengar. Tindak tutur (speech atcs) adalah ujaran yang dibuat sebagai bagian dari interaksi sosial (Putrayasa, 2014: 85).

Dalam penelitian ini penulis menggunakan pendekatan atau kajian pragmatik. Pragmatik adalah studi tentang makna yang disampaikan oleh penutur (atau penulis) dan ditafsirkan oleh pendengar (atau pembaca). Sebagai akibatnya studi ini lebih banyak berhubungan dengan analisis tentang apa yang dimaksudkan orang dengan tuturan-tuturanya dari pada dengan makna terpisah dari kata atau frasa yang digunakan dalam tuturan itu sendiri. Pragmatik adalah studi tentang maksud penutur (Yule, 2014: 3).

Tindak tutur dalam interaksi belajarmengajar merupakan salah satu bentuk pemakaian bahasa yang sesuai dengan topik pembicaraan, tujuan pembicaraan, situasi dan tempat berlangsungnya pembicaraan tersebut.

Dalam interaksi proses belajarmengajar di sekolah, guru sangat berperan dalam mendidik serta harus pandai menarik minat siswanya agar mengikuti kegiatan belajar-mengajar dengan baik dan tekun. , melalui penelitian ini akan dikaji mengenai tindak tutur guru dalam proses belajarmengajar pada TK Wulele Sanggula Dua Kelurahan Kambu kota Kendari. Karena penulis bermaksud untuk mengetahui jenisjenis tindak tutur apa saja yang disampaikan oleh guru kepada muridnya untuk menunjang proses belajar mengajar di TK tersebut, karena guru harus memilih bentuk tutur yang sesuai agar peserta didik (mitra tutur) dapat melakukan tindakan yang disebutkan dalam tuturan tersebut. Contohnya :

"Ani duduk di tempat dudukmu nak, jangan berkeliaran karena ibu guru akan memulai pelajaran".

Konteks tuturan : Dituturkan oleh seorang guru kepada muridnya ketika melihat ada murid yang sedang berkeliaran di ruang 1 slas pada saat proses belajarmengajar akan dimulai. Jenis tindak tutur direktif, bentuk tuturanya memerintah yaitu agar siswa duduk di tempat duduknya.

Data di atas merupakan salah satu tindak tutur yang disampaikan oleh guru kepada siswanya, tuturan gurunya sudah tepat dalam hal memerintah siswa untuk tertib saat poses belajar-mengajar akan berlangsung.

\section{7 | Jurnal BASTRA (Bahasa dan Sastra), Vol. 4 No.1, Edisi Januari 2019/e-ISSN: 2503-3875/ http://ojs.uho.ac.id/index.php/BASTRA}


Kemampuan peserta didik dalam merespon atau memahami tindak tutur guru di Taman Kanak-Kanak Wuleele Sanggula Dua Kelurahan Kambu Kota Kendari masih belum merata. Dalam hal ini peserta didik sudah bisa merespon dengan baik dan cepat, namun masih ada juga beberapa peserta didik yang belum bisa merespon dengan cepat apa yang dituturkan oleh gurunya. Oleh karena itu guru yang mengajar di Taman Kanak-Kanak Wulele Sanggula Dua Kelurahan Kambu Kota Kendari harus mempunyai strategi agar tuturanya bisa direspon dengan cepat oleh peserta didiknya dan yang terpenting masing-masing peserta didik mempunya tingkat kecerdasan yang berbeda-beda. Jadi, guru harus pandaipandai dalam hal mengorganisasikan tuturanya kepada setiap anak.

\subsection{Rumusan Masalah}

Berdasarkan latar belakang yang telah penulis paparkan tersebut maka rumusan masalah yang dikemukakan dalam penelitian ini adalah bagaimanakah jenis-jenis tindak tutur yang dikemukakan pada tuturan guru dalam proses

belajar-mengajar di Taman Kanak-Kanak Wulele Sanggula Dua Kelurahan Kambu Kota Kendari.

\subsection{Tujuan Penelitian}

Berdasarkan rumusan masalah yang ada dalam penelitian ini maka tujuan yang akan dicapai adalah memaparkan jenis-jenis tindak tutur guru dalam proses belajarmengajar di Taman Kanak-Kanak Wulele Sanggula Dua Kelurahan Kambu Kota Kendari.

\subsection{Manfaat Penelitian}

Manfaat dari penelitian ini diharapkan berguna untuk berbagai pihak, di antaranya :

1. Manfaat bagi Guru TK yaitu dapat membina dan menambah pengetahuan penggunaan bahasa guru yang mengajar di taman kanak-kanak demi pembenahan bahasa pada tindak tutur guru.

2. Manfaat bagi pembaca yaitu dapat menamabah wawasan dalam hal tindak tutur yang ada dalam proses belajarmengajar antara guru dan muridnya. Penelitian ini juga dapat di gunakan sebagai acuan dalam penelitian yang lain.

3. Manfaat bagi masyarakat yaitu penelitian ini dapat di gunakan untuk lebih memahami bidang kajian pragmatik khususnya mengenai tindak tutur.

\subsection{Batasan Operasional}

1. Pragmatik adalah kajian mengenai kemampuan pengguna bahasa untuk menyesuaikan kalimat dengan konteks sehingga kalimat itu patut dan tepat diujarkan.

2. Tindak tutur adalah kegiatan seseorang dalam menggunakan bahasa kepada mitra tutur dalam hal mengkomunikasikan sesuatu.

3. TK adalah salah satu bentuk pendidikan sekolah yang bertujuan untuk membantu meletakan dasar kearah perkembangan sikap, perilaku, pengetahuan, keterampilan dan daya cipta yang di perlukan oleh anak didik dalam menyesuaikan diri dengan keluarganya dan untuk pertumbuhan dan perkembangan selanjutnya.

4. Proses belajar -mengajar merupakan urutan pelaksanaan atau kejadian yang mengandung serangkaian perbuatan guru dan siswa atas dasar hubungan timbal balik yang berlangsung dalam situasi edukatif untuk mencapai tujuan tertentu.

\section{KAJIAN PUSTAKA \\ 1.1 Pengertian Bahasa dan Fungsi Bahasa 1.1.1 Pengertian Bahasa}

Bahasa merupakan alat komunikasi yang digunakan manusia, baik lisan 
maupun tulisan. Sumpah pemuda 1928 berisi tentang pengakuan bahwa bahasa Indonesia merupakan bahasa Nasional. Begitu pula dalam UUD 1945 PASAL 36 Menyatakan bahwa bahasa Indonesia merupakan bahasa Negara yang mempunyai dasar hukum (Sulastri, 2014: 2).

Lambang bunyi bahasa bersifat arbitrer. Artinya, hubungan antara lambang dengan yang dilambangkannya tidak bersifat wajib, bisa berubah, dan tidak dapat dapat dijelaskan mengapa lambang tersebut mengonsepi makna tertentu (Chaer, 2010: 12).

\subsubsection{Fungsi Bahasa}

Lestari dan Kurniawan (2011: 6-7) membagi fungsi bahasa secara umum yaitu: a. Bahasa Sebagai Sarana Komunikasi

Manusia tidak dapat hidup seorang diri. Dalam memenuhi kebutuhanya, setiap orang memerlukan kerja sama dengan orang lain. Mereka perlu berkomunikasi dalam berbagai lingkungan, tingkatan, dan kepentingan yang beraneka ragam, misalnya, komunikasi ilmiah, komunikasi bisnis dan komunikasi sosial.

b. Bahasa Sebagai Sarana Ekspresi Diri

Bahasa sebagai sarana ekspresi diri dapat dilakukan dari hal yang paling sederhana (saat sedih, gembira, marah, dan kecewa) sampai dengan tingkat yang kompleks (penulisan proposal, artikel, laporan penelitian, dan penulisan melalui media elektronik dengan beraneka ragam jenisnya).

c. Bahasa Sebagai Sarana IntegrasiAdaptasi

Anggota masyarakat hanya dapat dipersatukan secara efisien melalui bahasa. Dengan bahasa, setiap anggota masyarakat merasa terikat dengan kelompok sosial yang dimasukinya serta melakukan kerja sama dan meminimalisasi segala macam perselisihan.
Melalu bahasa juga, seseorang dapat belajar beradaptasi dengan lingkungan masyarakat tertentu yang memiliki adat istiadat, tata cara sosial, dan budaya yang berbeda-beda antara satu daerah dengan daerah lain. Apabila seseorang dapat menyesuaikan diri (adaptasi) maka ia pun dengan mudah dapat berbaur (berintegrasi) dengan anggota masyarakat lainnya. Dengan demikian seseorang akan bisa menggunakan bahasa yang paling tepat sesuai dengan situasi, topik pembicaraan, dan orang yang diajak berbicara.

d. Bahasa Sebagai Sarana Kontrol Sosial

Bahasa sebagai sarana kontrol sosial berfungsi untuk mengendalikan komunikasi agar orang yang terlibat dalam komunikasi dapat saling memahami. Mereka yang berkomunikasi dapat saling memberi saran, kritik, nasihat atau sekedar berbasa-basi.

e. Bahasa Sebagai Sarana Membangun Kecerdasan.

Kecerdasan adalah kemampuan memanfaatkan potensi, pengalaman, pengetahuan dan situasi sehingga menghasilkan kreativitas baru yang menguntungkan dirinya dan masyarakatnya. Kecerdasan berbahasa terkait dengan kemampuan sesorang untuk berpikir dan menyampaikan ide-idenya secara logis, sistematis dan kreatif. Karena kecerdasan berbahasa pula, seseorang dapat memahamai pikiran orang lain yang kemungkinan dapat meningkatkan kecerdasanya.

f. Bahasa Sebagai Sarana Membangun Karakter

Bahasa adalah pembeda kelas yang sebenarnya karena bahasa itu mencerminkan tingkat kecerdasan seseorang. Dengan kemampuan berbahasa, seseorang dapat mengembangkan profesinya dan dapat bernegosiasi dengan orang lain. Kemampuan berbahasa seseorang yang didukung oleh kecerdasan lainnya sangat berpengaruh terhadap kepribadian 
seseorang. Bahasa menunjukan bangsa, bahasa menunjukan karakter dan kepribadian seseorang.

\subsection{Pengertian Pragmatik}

Pragmatik adalah studi tentang makna yang disampaikan oleh penutur (penulis) dan ditafsirkan oleh pendengar (pembaca). Sebagai akibatnya studi ini lebih banyak berhubungan dengan analisis tentang apa yang dimaksudkan orang dengan tuturantuturannya dari pada dengan makna terpisah dari kata atau frasa yang digunakan dalam tuturan itu sendiri. Pragmatik adalah studi tentang maksud penutur. (Yule,2014: 3).

Pragmatik adalah telaah mengenai segala aspek makna yang tidak tercakup dalam teori semantik, atau dengan perkataan lain: memperbincangkan segala aspek makna ucapan yang tidak dapat dijelaskan secara tuntas oleh referensi langsung kepada kondisi-kondisi kebenaran kalimat yang diucapkan (Tarigan, 1990: 33).

Parker (dalam Putrayasa, 2014: 1) mendefenisikan pragmatik sebagai cabang ilmu bahasa yang mempelajari struktur bahasa secara eksternal. Adapun yang dimaksud dengan hal tersebut adalah bagaimana sesungguhnya satuan lingual tertentu dapat digunak an dalam komunikasi yang sebenarnya. Parker dengan tegas membedakan sosok pragmatik dengan studi tata bhasa yang dianggapnya sebagai studi seluk beluk bahasa secara internal.

Levinson (dalam Putrayasa, 2014: 1) memberikan setidaknya dua pengertian pragmatik yang dikaitkan dengan konteks, yaitu (a) pragmatik adalah kajian ihwal hubungan antara bahasa dan konteks yang digramatikalisasikan dan dikodekan dalam struktur bahasa, dan (b) pragmatik adalah kajian ihwal kemampuan pengguna bahasa untuk menyesuaikan kalimat dengan konteks sehingga kalimat itu patut atau tepat diujarkan.
Dari beberapa pengertian pragmatik yang disampaikan oleh para ahli dapat disimpulkan bahwa pragmatik adalah kajian mengenai hubungan antara bahasa yang digunakan untuk berkomunikasi dalam konteks dan situasi pemakaianya.

\subsection{Tindak Tutur}

\subsubsection{Pengertian Tindak Tutur}

Menurut Putrayasa (2014: 85) tindak tutur (istilah kridaklasana) pertuturan/speech act, speech event: pengujaran kalimat untuk menyatakan agar suatu maksud dari pembicara diketahui pendengar. Tindak tutur adalah ujaran yang dibuat sebagai bagian dari interaksi sosial. Tindak tutur merupakan bagian dari peristiwa tutur dan peristiwa tutur merupakan bagian dari situasi tutur. Setiap peristiwa tutur terbatas pada kegiatan atau aspek-aspek kegiatan yang secara langsung diatur oleh kaidah atau norma bagi penutur.

\subsubsection{Jenis Tindak Tutur}

Searle (dalam Putrayasa, 2014: 87-88) mengemukakan bahwa secara pragmatik setidak-tidaknya terdapat tiga jenis tindakan yang dapat diwujudkan oleh seorang penutur, yakni tindak lokusi (locutionary act), tindak ilokusi (illocutionary act), dan tindak ${ }^{\text {perlokusi }}$ (perlocutionary act).

\section{Tindak Iokusi}

Tindak lokusi adalah tindak tutur untuk menyatakan sesuatu. Konsep lokusi juga adalah konsep yang berkaitan dengan proposisi kalimat. Kalimat atau tuturan dalam hal ini dipandang sebagai suatu satuan yang terdiri atas dua unsur, yakni subjek/topik dan predikat/comment. Selanjutnya dikatakan bahwa tindak lokusi adalah tindak tutur yang relatif paling mudah untuk diidentifikasi karena pengidentifikasiannya cenderung dapat dilakukan tanpa menyertakan konteks tuturan yang tercakup dalam situasi tutur.

Contoh kalimat :

\section{0 | Jurnal BASTRA (Bahasa dan Sastra), Vol. 4 No.1, Edisi Januari 2019/e-ISSN: 2503-3875/ http://ojs.uho.ac.id/index.php/BASTRA}


"Ikan paus adalah binatang mamalia terbesar di samudra"

Kalimat tersebut diutarakan sematamata hanya menginformasikan sesuatu tanpa tendensi untuk melakukan sesuatu, apalagi intuk memengaruhi lawan tuturnya. Kalimat tersebut hanya berupa informasi yang tidak berdampak apa-apa terhadap mitra tuturnya.

\section{Tindak Ilokusi}

Tindak ilokusi adalah sebuah tuturan selain berfungsi untuk mengatakan atau menginformasikan sesuatu, dapat juga digunakan untuk melakukan sesuatu. Tindak ilokusi disebut sebagai The Act of Doing Something. Contohnya : "Saya tidak bisa datang".

Kalimat tersebut jika diutarakan oleh seseorang kepada temanya yang baru saja berulang tahun, kalimat itu tidak hanya berfungsi untuk menyatakan atau menginformasikan sesuatu tetapi juga untuk melakukan sesuatu, yakni bermaksud untuk meminta maaf karena tidak bisa hadir dalam pesta ulang tahun. Informasi ketidakhadiran penutur dalam hal ini kurang begitu penting karena besar kemungkinan lawan tutur sudah mengetahui hal tersebut.

\section{Tindak Perlokusi}

Tindak perlokusi yaitu tindakan untuk memengaruhi lawan tutur seperti memalukan, mengintimidasi, membujuk dan lain-lain. Tindak ini disebut The Act of Affecting Someone. Contohnya : "Kemarin saya sangat sibuk". Jika kalimat ini diutarakan oleh seseorang yang tidak dapat menghadiri undangan rapat kepada orang yang mengundangnya, kalimat ini merupakan tindak ilokusi memohon maaf, dan efek perlokusi yang diharapkan adalah orang yang mengundang dapat memakluminya.

Dalam bukunya yang berjudul Dasar-Dasar Pragmatik, Wijana (2006) (dalam Putrayasa 2014: 92-93) menguraikan adanya dua jenis tindak tutur dalam berbahasa, yakni : (1) tindak tutur langsung dan tindak tutur tidak langsung, (2) tindak tutur literal dan tindak tutur tidak literal.

\subsection{Klasifikasi Tindak Tutur}

Putrayasa (2014: 90-91) Pembagian tindak tutur berdasarkan maksud penutur ketika berbicara (ilokusi) dibagi dalam lima jenis. Pembagian tersebut didasarkan atas asumsi "Berbicara menggunakan suatu bahasa adalah mewujudkan perilaku dalam aturan yang tertentu". Kelima tindak tutur tersebut adalah sebagai berikut:

1. Tindak tutur representatif yaitu tindak tutur yang berfungsi untuk menetapkan dan menjelaskan sesuatu apa adanya.Tindak tutur ini, seperti menyatakan, melaporkan, memberitahukan, menjelaskan, mempertahankan menolak dan lain-lain. Tindak menyatakan, mempertahankan maksudnya adalah penutur mengucapkan sesuatu, maka mitra tutur percaya terhadap ujaran penutur. Tindak melaporkan, memberitahukan maksudnya katika penutur mengujarkan sesuatu, maka penutur percaya bahwa telah terjadi sesuatu. Tindak menolak, menyangkal, maksudnya penutur mengucapkan sesuatu maka mitra tutur percaya bahwa terdapat alasan untuk tidak percaya.

2. Tindak tutur komisif, yaitu tindak tutur yang berfungsi untuk mrndorong pembicaraan melakukan sesuatu seperti berjanji, bernazar, bersumpah, dan ancaman. Komisisif terdiri atas dua tipe, yaitu promises (menjanjikan) dan offers (menwarkan).

3. Tindak tutur direktif, yaitu bentuk tutur yang dimaksudkan penuturnya untuk mempengaruhi mitra tutur agar melakukan tindakan, misalnya memesan, 
memerintah, memohon, menasehati, melarang dan sebagainnya

4. Tindak tutur ekspresif, yaitu tindak tutur ini brfungsi untuk mengekspresikan perasaan dan sikap. Tindak tutur ini berupa tindak meminta maaf, berterima kasih, menyampaikan ucapan selamat, memuji, mengkritik. Penutur mengekspresikan perasaan tertentu kepada mitra tutur baik yang berupa rutinitas maupun yang murni. Perasaan dan pengekspresian penutur untuk jenis situasi tertentu yang dapat berupa tindak penyampaian salam (greeting) yang mengekspresikan rasa senang karena bertemu dan melihat seseorang, tindak berterima kasih (thanking) yang mengekspresikan rasa syukur karena telah menerima sesuatu. Tindak meminta maaf (apologizing) mengekspresikan simpati karena penutur telah melukai atau mengganggu mitra tutur.

5. Tindak tutur deklaratif, yaitu tindak tutur yang berfungsi untuk memantapkan sesuatu yang dinyatakan, antara lain dengan setuju, tidak setuju, benar-benar salah dan sebagainya.

\subsection{Karakteristik Guru Taman Kanak- Kanak dan Anak Usia Dini \\ 1.5.1 Karakteristik Guru Anak Usia Dini}

Anggraeni (2017 : 31) karakteristik guru anak usia dini yaitu :

a. Menunjukan rasa cinta dan menghargai pada semua anak

b. Dapat menunjukan rasa percaya diri dan rasa nyaman pada anak

c. Mampu bekerja keras

d. Mampu bertingkah laku sopan terhadap orang lain.

e. Mampu bekerja keras

f. Bersedia menyediakan waktu tambahan untuk menyelesaikan tugas profesi

g. Tepat waktu h. Dapat menjaga rahasia

i. Bersedia dikoreksi apabila membuat kesalahan

j. Mengamati peran kelompok yang ditangani

\subsubsection{Karkteristik Anak Usia Dini}

(Anggraeni, 2017 : 35) Anak usia dini memiliki karakteristik yang khas, baik secara fisik, sosial, moral, dan sebagainya. Karakteristik anak usia dini antara lain :

a. Memiliki rasa ingin tahu yang besar

b. Merupakan pribadi yang uik

c. Suka berfantasi dan berimajinasi

d. Masa paling potensial untuk belajar

e. Menunjukkan sikap egosenntris

f. Memiliki rentang daya konsentrasi yang pendek

g. Sebagai bagian dari makhluk sosial

\section{Guru Sebagai Pembimbing}

Sukmadinata (2016: 253-254) Selain sebagai pendidik dan pengajar juga guru punya peran sebagai pembimbing, perkembagan anak tidak selalu mulus dan lancer, adakalanya lambat dan mungkin juga berhenti sama sekali. Dalam situasi seperti itu mereka perlu mendapatkan bantuan atau bimbingan. Dalam upaya membantu anak mengatasi kesulitan atau hambatan yang di hadapi dalam perkembangannya, guru berperan sebagai pembimbing. Sebagai pembimbing, guru perlu memiliki pemahaman yng seksama tentang para siswanya, memahami segala potensi dan kelemahanya, masalah dan kesulitan-kesulitannya,dengansegala latar belakangnya. Agar tercapai kondisi seperti itu, guru perlu banyak mendekati para siswa, membina hubungan yang lebih dekat dan akrab, melakukan pengamatan dari dekat serta mengadakan dialog-dialog langsung.

\subsection{Keterampilan Guru dalam Proses Belajar Mengajar}


Hasibuan dan Moedjiono (2012: 58-88) menyebutkan beberapa macam keterampilan dasar yang diutamakan dalam proses belajar mengajar, yaitu :

1. Keterampilan memberi penguatan

2. Memberikan penguatan diartikan dengan tingkah laku guru dalam merespons secara positif suatu tingkah laku siswa yang memungkinkan tingkah laku tersebut timbul kembali.

3. Keterampilan Bertanya

Bertanya merupakan ucapan verbal yang meminta respons dari seseorang yyang dikenali. Respons yang diberikan dapat berupa pengetahuan sampai dengan halhal yang merupakan hasil pertimbangan. Jadi bertanya merupakan stimulus efektif yang mendorong kemampuan berpikir

4. Keterampilan menggunakan variasi

Menggunakan variasi diartikan sebagai perbuatan guru dalam konteks proses belajar-mengajar yang bertujuan mengatasi kebosanan siswa, sehingga dalam proses belajarnya siswa senantiasa menunjukkan ketekunan, keantusiasan, serta berperan secara aktif.

5. Keterampilan menjelaskan

Menjelaskan berarti menyajikan informasi lisan yang diorganisasikan secara sistematis dengan tujuan menunjukan hubungan. Penekanan memberikan penjelasan adalah proses penalaran siswa, dan bukan indoktrinasi.

6. Keterampilan membuka dan menutup pelajaran

Membuka pelajaran diartikan dengan perbuatan guru untuk menciptakan suasana siap mental dan menimbulkan perhatian siswa agar terpusat kepada apa yang dipelajari. Menutup pelajaran adalah kegiatan guru untuk mengakhiri kegiatan inti pelajaran. Maksudnya adalah memberikan gambaran menyeluruh tentang apa yang telah dipelajari siswa, Mengetahui tingkat pencapaian siswa, dan tingkat keberhasilan guru dalam proses belajarmengajar.

7. Keterampilan mengajar kelompok kecil dan perorangan

Mengajar kelompok kecil dan perorangan diartikan sebagai perbuatan guru dalam konteks belajar-mengajar yang hanya melayani 3-8 siswa untuk kelompok kecil, dan hanya seorang untuk perorangan. Pada dasarnya bentuk pengajaran ini dapat dikerjakan dengan membagi kelas dalam kelompokkelompok yang lebih kecil.

8. Keterampilan mengelola kelas

Keterampilan mengelola kelas merupakan keterampilan guru untuk menciptakan dan memelihara kondisi belajar yang optimal dan mengembalikannya ke kondisi yang optimal jika terjadi terganggu, baik dengan cara mendisiplinkan ataupun melakukan kegiatan remedial

9. Keterampilan membimbing diskusi kelompok kecil

Diskusi kelompok keccil adalah suatu proses yang teratur dengan melibatkan sekelompok siswa dalam interaksi tatap muka kooperatif yang optimal dengan tujuan.

10. Keterampilan membimbing diskusi kelompok kecil

Diskusi kelompok keccil adalah suatu proses yang teratur dengan melibatkan sekelompok siswa dalam interaksi tatap muka kooperatif yang optimal dengan tujuan.

\section{METODE DAN TEKNIK PENELITIAN}

\subsection{Jenis dan Metode Penelitian}

\subsubsection{Jenis Penelitian}

Jenis penelitian ini tergolong penelitian lapangan, sebab peneliti terlibat langsung dalam pengambilan dan pengumpulan data. Semua data nantinya yang sesuai dengan masalah yang ada dalam penelitian itu 
diperoleh di lokasi tempat penelitianya yakni di TK Wulele Sanggula Dua Kelurahan Kambu Kota Kendari.

\subsubsection{Metode Penelitian}

Metode yang digunakan dalam penelitian ini adalah metode deskriptif kualitatif, yaitu sebuah metode yang menyajikan berupa fakta mengenai data yang kita peroleh dengan cara memahami fenomena yang dialami oleh subjek yang kita teliti.

\subsection{Data dan Sumber Data}

Data dalam penelitian ini berupa tuturan guru yang ada di Taman Kanak-Kanak Wulele Sanggula Dua Kelurahan Kambu Kota Kendari. Sumber data dalam penelitian ini adalah guru di Taman KanakKanak Wulele Sanggula Dua Kelurahan Kambu Kota Kendari.

\subsection{Teknik Pengumpulan Data}

Teknik yang digunakan untuk pengumpulan data dalam penelitian ini adalah teknik rekam sebagai teknik dasar. Dengan menggunakan teknik ini peneliti bisa merekam penggunaan bahasa guru dan peserta didik dalam proses belajar mengajar. Teknik simak bebas libat cakap (SBLC), teknik catat, dan teknik wawancara digunakan sebagai teknik lanjutan.

\subsection{Teknik Analisis Data}

Berdasarkan teknik pengumpulan data yang digunakan, maka data dianalisis secara deskriptif kualitatif menggunakan metode analisis padan pragmatis. Metode padan pragmatis dipilih sebagai metode analisis data karena metode ini alat penentunya adalah mitra wicara atau mitra tutur, setiap tuturan dikategorikan berdasarkan bentuk. A pun langkah langkah dalam menganalisis data meliputi, sebagai berikut :

1. Mengidentifikasi setiap tuturan yang disampaikan oleh guru dan murid pada proses belajar-mengajar yang berlangsung di Taman Kanak-Kanak Wulele Sanggula Dua Kelurahan Kambu Kota Kendari yang diperoleh melalui rekaman, wawancara dan catatan.

2. Mengklasifikasikan dan menganalisis jenis-jenis tindak tutur apa saja yang di sampaikan oleh guru dan murid di Taman Kanak-Kanak Wulele Sanggula Dua Kelurahan Kambu Kota Kendari.

3. Menyimpulkan hasil analisis.

\section{HASIL PENELITIAN DAN PEMBAHASAN}

\subsection{Data}

\section{Data 1 Tuturan Guru}

\section{(1) "Ayo anak-anak, mana sikap berdoa!"} Konteks tuturan :(Anak-anak mengikuti apel pagi di luar kelas dan guru memberikan aba-aba seperti biasa sebelum mereka berdoa).

Tuturan seorang guru kepada muridnya agar bersiap-siap untuk berdoa bersama-sama sebelum masuk dalam ruangan kelas.

(2) "Sebelummasuk ruangan sepatunya dibuka dan disimpan di tempat sepatu yah anak-anak."

Konteks tuturan: (Setelah selesai apel pagi, anak-anak berlarian memasuki ruang kelas).

Tuturan seorang guru kepada muridnya ketika melihat anak-anak yang berbondong-bondong masuk ke ruang kelas, guru menasehati muridnya untuk membuka sepatunya sebelum masuk ruangan.

(3) " Ayo anak-anak, siapa yang mau menabung ini hari kumpul sama ibu guru!"

Konteks tuturan : ( Setelah semua anak memasuki ruangan, guru menyampaikansesu atu)

Tuturan seorang guru kepada muridmuridnya menyampaikan kalau yang ingin menabung untuk segera mengumpulkan kepada ibu guru.

\section{4 | Jurnal BASTRA (Bahasa dan Sastra), Vol. 4 No.1, Edisi Januari 2019/e-ISSN: 2503-3875/ http://ojs.uho.ac.id/index.php/BASTRA}


(4) "Aqila, ayo pimpin doa belajar!"

Konteks tuturan : ( Setelah menabung anak-anak bersiap-siap untuk berdoa sebelum belajar).

Tuturan seorang guru kepada muridnya yang bernama Aqila, memerintahkan untuk memimpin doa sebelum mereka memulai pelajaran.

(5) "Ayo anak-anak sbelum belajar kita zikir dulu dengan membaca suratsurat pendek, supaya setan dia jauhjauh dari kita."

Konteks tuturan : (Setelah membaca doa sebelum belajar, anak-anak seperti biasa membaca surat-surat pendek)

Tuturan seorang guru kepada muridmuridnya, menyuruh agar mereka berzikir dengan membaca surah-surah pendek agar nantinya pada saat proses belajar-mengajar dapat berlangsung dengan lancar dan tidak mendapat gangguan.

(6) "Ayo anak-anak, baca ayat kursi!"

Konteks tuturan: (Setelah membaca surat Al-ikhlas, guru lalu melanjutkan dengan membaca salah satu surat yaitu ayat kursi).

Tuturan seorang guru kepada muridnya menyuruh mereka untuk membaca ayat kursi sebelum proses belajar-mengajar akan dimulai.

(7) "Yang tidak baca doa nanti kalau belajar sebentar diganggu sama setan."

Konteks tuturan : (Pada saat berdoa sedang berlangsung, guru melihat ada muridnya yang tidak serius membaca doa).

Tuturan seorang guru kepada murid-muridnya yang memberitahukan kalau anak-anak yang tidak membaca doa akan diganggu setan pada saat proses belajar-belajar mengajar berlangsung.

(8) "Siapa yang tidak mandi tadi pagi?"
Konteks tuturan: (Setelah selesai membaca doa, guru berbincangbincang dengan muridnya).

Tuturan seorang guru kepada muridnya untuk menanyakan siapa-siapa di antara mereka yang tidak mandi pagi saat ak

\subsection{Analisis Data}

Teori yang digunakan dalam menganalisis data pada penelitian ini, penulis menggunakan teori Putrayasa yaitu pengklasifikasian (ilokusi) berdasarkan maksud penutur ketika berbicara ada lima jenis yaitu :

1. Tindak tutur representatif yaitu tindak tutur yang berfungsi untuk menetapkan dan menjelaskan sesuatu apa adanya.Tindak tutur ini, seperti menyatakan, melaporkan, memberitahukan, menjelaskan, mempertahankan menolak dan lain-lain.

2. Tindak tutur komisif yaitu tindak tutur yang berfungsi untuk mrndorong pembicaraan melakukan sesuatu seperti berjanji, bernazar, bersumpah, dan ancaman.

3. Tindak tutur direktif yaitu bentuk tutur yang dimaksudkan penuturnya untuk mempengaruhi mitra tutur agar melakukan tindakan, misalnya memesan, memerintah, memohon, menasehati, melarang dan sebagainnya

4. Tindak tutur ekspresif yaitu tindak tutur ini brfungsi untuk mengekspresikan perasaan dan sikap. Tindak tutur ini berupa tindak meminta maaf, berterima kasih, menyampaikan ucapan selamat, memuji, mengkritik.

5. Tindak tutur deklaratif, yaitu tindak tutur yang berfungsi untuk memantapkan sesuatu yang dinyatakan, antara lain dengan setuju, tidak setuju, benar-benar salah dan sebagainya.

Data 1 (1) "Ayo anak-anak mana sikap
berdoa!" 
Konteks tuturan : (Anak-anak mengikuti apel pagi di luar kelas dan guru memberikan aba-aba seperti biasa sebelum mereka berdoa).

Tuturan seorang guru kepada muridnya agar bersiap-siap untuk berdoa bersama-sama sebelum masuk dalam ruangan kelas.

Jenis tindak tutur yang terdapat dalam data 1 adalah tindak direktif. Tindak direktif yaitu bentuk tutur yang dimaksudkan penuturnya untuk mempengaruhi mitra tutur agar melakukan tindakan, misalnya memesan, memerintah, memohon, menasihati, melarang dan sebagainnya. Tindak direktif yang terdapat dalam data (1) merupakan tindak direktif suruhan. Pada tuturan (1) guru memberikan arahan "anak-anak mana sikap berdoa" arahan tersebut sudah dipahami, sehingga muridnya langsung menanggapi tanpa harus bertanya terlebih dahulu. Seharusnya tuturan yang benar adalah " anak-anak bagaimana sikap berdoa”.

\section{Data 2}

(2) "Sebelum masuk ruangan sepatunya dibuka dan disimpan di tempat sepatu yah anak-anak."

Konteks tuturan : (Setelah selesai apel pagi, anak-anak berlarian memasuki ruang kelas).

Tuturan seorang guru kepada muridnya ketika melihat anak-anak yang berbondong-bondong masuk ke ruang kelas, guru menyuruh muridnya untuk membuka sepatunya sebelum masuk ruangan.

Jenis tindak tutur yang terdapat dalam data 2 adalah tindak direktif. Tindak direktif yaitu bentuk tutur yang dimaksudkan penuturnya untuk mempengaruhi mitra tutur agar melakukan tindakan, misalnya memesan, memerintah, memohon, menasihati, melarang dan sebagainnya. Tindak direktif yang terdapat dalam data (2) merupakan tindak direktif menyuruh. Pada tutura (2) guru menyuruh murid-muridnya untuk membuka sepatu mereka dan menyimpannya di rak sepatu ketika hendak masuk ruangan dan tuturan tersebut langsung diikuti oleh murid.

\section{Data 3}

(3) “ Ayo anak-anak, siapa yang mau menabung ini hari kumpul sama ibu guru!",

Konteks tuturan : ( Setelah semua anak memasuki ruangan, guru menyampaikan sesuatu)

Tuturan seorang guru kepada muridmuridnya menyampaikan kalau yang ingin menabung untuk segera mengumpulkan kepada ibu guru.

Jenis tindak tutur yang terdapat dalam data (3) merupakan tindak direktif. Tindak direktif yaitu bentuk tutur yang dimaksudkan penuturnya untuk mempengaruhi mitra tutur agar melakukan tindakan, misalnya memesan, memerintah, memohon, menasihati, melarang dan sebagainnya. Tindak direktif yang terdapat dalam data (3) adalah tindak direktif suruhan. Pada tuturan (3) guru menyuruh muridnya untuk mengumpulkan uang tabungan mereka apabila ada yang ingin menabung dan anak-anak langsung mengiindahkan apa yang dituturkan oleh gurunya tersebut.

\section{Data 4}

(4) "Aqila, ayo pimpin doa belajar!"

Konteks tuturan : ( Setelah menabung anak-anak bersiap-siap untuk berdoa sebelum belajar).

Tuturan seorang guru kepada muridnya yang bernama Aqila, memerintahkan 
untuk memimpin doa sebelum mereka memulai pelajaran.

Jenis tindak tutur yang terdapat dalam data (4) merupakan tindak direktif. Tindak direktif yaitu bentuk tutur yang dimaksudkan penuturnya untuk mempengaruhi mitra tutur agar melakukan tindakan, misalnya memesan, memerintah, memohon, menasehati, melarang dan sebagainnya. Tindak direktif yang terdapat pada tuturan (4) adalah tindak direktif suruhan. Pada tuturan (4) guru menyuruh Aqila untuk mempin doa sebelum mereka akan memulai pembelajaran, Aqila lalu melakukan apa yang diperintahkan oleh guru.

\section{Data 5}

(5) "Ayo anak-anak sebelum belajar kita zikir dulu dengan membaca suratsurat pendek supaya setan dia jauhjauh dari kita."

Konteks tuturan : (Setelah membaca doa sebelum belajar, anak-anak seperti biasa membaca surat-surat pendek).

Tuturan seorang guru terhadap muridnya, menyuruh agar mereka berdzikir dengan membaca surah-surah pendek agar nantinya pada saat proses belajar mengajar dapat berlangsung dengan lancar dan tidak mendapat gangguan.

Jenis tindak tutur yang terdapat dalam data (5) merupakan tindak direktif. Tindak direktif yaitu bentuk tutur yang dimaksudkan penuturnya untuk mempengaruhi mitra tutur agar melakukan tindakan, misalnya memesan, memerintah, memohon, menasehati, melarang dan sebagainnya. Tindak direktif yang terdapat pada tuturan (5) adalah tindak direktif suruhan. Tuturan (5) guru menyuruh muridnya untuk berzikir terlebih dahulu dengan membaca surat-surat pendek sebelum memulai pembelajaran.

\section{Data 6}

(6) "Anak-anak baca ayat kursi!"

Konteks tuturan: (Setelah membaca surat Al-ikhlas, guru lalu melanjutkan dengan membaca salah satu surat yaitu ayat kursi).

Tuturan seorang guru kepada muridnya menyuruh mereka untuk membaca ayat kursi sebelum proses belajar-mengajar akan dimulai.

Jenis tindak tutur yang terdapat dalam data (6) merupakan tindak direktif. Tindak direktif yaitu bentuk tutur yang dimaksudkan penuturnya untuk mempengaruhi mitra tutur agar melakukan tindakan, misalnya memesan, memerintah, memohon, menasihati, melarang dan sebagainnya. Tindak direktif yang terdapat dalam data (6) adalah tindak direktif suruhan. Pada tuturan (6) guru menyuruh muridnya untuk membaca ayat kursi ketika proses belajar-mengajar akan dimulai.

\section{Data 7}

(7) "Yang tidak baca doa belajar, nanti kalau belajar sebentar diganggu setan."

Konteks tuturan : (Pada saat berdoa sedang berlangsung, guru melihat ada muridnya yang tidak serius membaca doa).

Tuturan seorang guru kepada murid-muridnya yang memberitahukan kalau anak-anak yang tidak membaca doa akan diganggu setan pada saat proses belajar-belajar mengajar berlangsung.

Jenis tindak tutur yang terdapat dalam data (7) adalah tindak representatif. Tindak tutur representatif yaitu tindak tutur yang berfungsi untuk menetapkan dan 
menjelaskan sesuatu apa adanya. Seperti menyatakan, melaporkan, memberitahukan, menjelaskan, mempertahankan, menolak dan sebagainya. Tindak representatif yang terdapat dalam tuturan (7) merupakan tindak representatif memberitahukan. Pada tuturan (7) guru memberitahukan kepada muridnya, apabila ada yang tidak membaca doa belajar maka pada saat proses belajar-mengajar akan diganggu oleh setan.

\section{Data 8}

(8) "Siapa yang tidak mandi tadi pagi, angkat tangannya!"

Konteks tuturan: (Setelah selesai membaca doa, guru berbincangbincang dengan muridnya).

Tuturan seorang guru kepada muridnya yang menyuruh mereka mengangkat tangan kalau ada yang tidak mandi pagi saat akan berangkat ke sekolah.

Jenis tindak tutur yang terdapat dalam data (8) merupakan tindak direktif. Tindak direktif yaitu bentuk tutur yang dimaksudkan penuturnya untuk mempengaruhi mitra tutur agar melakukan tindakan, misalnya memesan, memerintah, memohon, menasihati, melarang dan sebagainnya. Tindak direktif yang terdapat dalam data (8) adalah tindak direktif suruhan. Pada tuturan (8) guru menyuruh muridnya untuk mengangkat tangan apabila ada yang tidak mandi pagi keetika hendak ke sekkolah.

\section{Data 9}

(9) " Gambar ini namanya matahari anakanak."

Konteks tuturan: ( Setelah guru memberikan pengantar, mereka lalu masuk materi belajar).
Tuturan seorang guru kepada muridnya saat memberitahukan kepada muridnya bahwa gambar yang gurunya pegang adalah gambar matahari. Karena materi pembelajaran mereka berkaitan dengan matahari.

Jenis tindak tutur yang terdapat dalam data (9) merupakan tindak representatif. Tindak tutur representatif yaitu tindak tutur yang berfungsi untuk menetapkan dan menjelaskan sesuatu apa adanya. Seperti menyatakan, melaporkan, memberitahukan, menjelaskan, mempertahankan,menolak dan sebagainya. Tindak representave yang terdapat dalam data (9) adalah tindak representatif memberitahukan. Pada tuturan (9) guru memberitahukan mengenai gambar yang ia pegang, bahwa gambar itu adalah gambar matahari.

\section{Data 10}

(10) "Coba sebutkan matahari terbit di sebelah mana anak-anak."

Konteks tuturan :(Saat proses pembawaan materi, guru menanyakan mengenai matahari kepada muridnya). Tuturan seorang guru kepada muridnya yang menyuruh muridnya menyebutkan matahari itu terbit di sebelah mana, untuk mengetes tingkat pemahaman mereka mengenai matahari.

Jenis tindak tutur yang terdapat dalam data (10) merupakan tindak direktif. Tindak direktif yaitu bentuk tutur yang dimaksudkan penuturnya untuk mempengaruhi mitra tutur agar melakukan tindakan, misalnya memesan, memerintah, memohon, menasihati, melarang dan sebagainnya. Tindak direktif yangterdapat dalam 
data (10) adalah tindak direktif suruhan. Padatuturan (10) guru menyuruh muridnya untuk menyebutkan mengenai matahari itu terbit di sebelah mana.

\section{Data 11}

(11) "Jangan ribut anak-anak, kalau ribut berarti temanya setan."

Konteks tuturan :(Saat proses pembelajaran, guru melihat ada salah satu murid yang ribut).

Tuturan seorang guru kepada muridnya melarang mereka untuk ribut dan memberi peringatan kalau yang ribut berarti temanya setan agar anak-anak bisa lebih mendengar arahan yang disampaikan gurunya.

Jenis tindak tindak tutur yang terdapat dalam data (11) adalah tindak direktif dan representatif. Tindak direktif yaitu bentuk tutur yang dimaksudkan penuturnya untuk mempengaruhi mitra tutur agar melakukan tindakan, misalnya memesan, memerintah, memohon, menasihati, melarang dan sebagainnya. Tindak direktif yang terdapat dalam data (11) adalah tindak direktif larangan, pada tuturan (11) guru melarang muridnya untuk ribut.

Tindak tutur representatif yaitu tindak tutur yang berfungsi untuk menetapkan dan menjelaskan sesuatu apa adanya. Seperti menyatakan, melaporkan, memberitahukan, menjelaskan, mempertahankan, menolak dan sebagainya. Tindak representatif yang terdapat dalam tuturan (11) merupakan tindak representatif menjelaskan. Pada tuturan (11) guru menjelaskan bahwa apabila murid-murid itu ribut maka mereka adalah temannya setan.

\section{Data 12}

(12) "Aceng, lain kali kalau tidak hadir ke sekolah harus ada

keterangannya yah."

Konteks tuturan :(Di sela-sela proses pembelajaran, guru memberikan arahan kepada salah satu murid yang tidak hadir minggu lalu)

Tuturan seorang guru kepada muridnya yang menyuruh Aceng untuk berjanji kalau tidak hadir ke sekolah harus ada keterangan.

Jenis tindak tutur yang terdapat dalam data (12) merupakan tindak komisif, yaitu tindak tutur yang berfungsi untuk mendorong pebicara melakukan sesuatu seperti berjanji, bernazar, bersumpah dan ancaman. Tindak komisisf yang terdapat dalam data (12) adalah tindak komisif berjanji. Tuturan (12) Aceng berjanji kepada gurunya untuk menyertakan keterangann apabila nanti ia tidak hadir ke sekolah.

\section{Data 13}

(13) "Anak-anak siapa yang tahu rukun Islam ada berapa? kalau yang tahu angkat tangannya."

Konteks tuturan : (Setelah guru selesai menegur Aceng, guru masuk materi pembelajaran selanjutnya).

\section{9 | Jurnal BASTRA (Bahasa dan Sastra), Vol. 4 No.1, Edisi Januari 2019/e-ISSN: 2503-3875/ http://ojs.uho.ac.id/index.php/BASTRA}


Tuturan seorang guru kepada muridnya menanyakan tentang rukun Islam itu ada berapa untuk mengetes pengetahuan dari murid-muridnya.

Jenis tindak tutur yang terdapat dalam data (13) merupakan tindak direktif. Tindak direktif yaitu bentuk tutur yang dimaksudkan penuturnya untuk mempengaruhi mitra tutur agar melakukan tindakan, misalnya memesan, memerintah, memohon, menasihati, melarang dan sebagainnya. Tindak direktif yang terdapat pada tuturan (13) adalah tindak direktif suruhan. Tuturan (13) guru menyuruh atau meminta muridnya untuk mengangkat tangannya apabila ada yang tahu mengenai rukun Islam.

\section{PENUTUP}

\subsection{Kesimpulan}

Berdasarkan pembahasan hasil penelitian, dapat disimpulkan bahwa jenisjenis tindak tutur yang terdapat pada Taman Kanak-Kanak Wulele Sanggula Dua Kelurahan Kambu Kota Kendari yaitu jenis tindak tutur representatif, tindak tutur komisif, tindak tutur direktif dan tindak tutur ekspresif. Namun yang lebih banyak dipakai dalam tuturan guru adalah jenis tindak tutur direktif, yaitu jenis tindak tutur yang berfungsi untuk mendorong pendengar melakukan sesuatu. Misalnya menyuruh, melarang, perintah, meminta dan sebagainnya.

\subsection{Saran}

Berdasarkan hasil pennelitian, yang menjadi saran penelitian ini adalah :

1. Agar pembaca dapat memberikan masukkan dalam penelitian ini

2. Bagi guru, agar bisa memahamai bagaimana cara pemilihan tuturan- tuturan yang sesuai agar dapat menunjang proses pembelajaran itu terlaksana dengan baik.

3. Semua hasil penlitian yang terdapat dalam Tindak Tutur Guru dalam Proses Belajar-Mengajar pada Taman KanakKanak Wulele Sanggula Dua Kelurahan Kambu Kota Kendari dapat dijadikan sebagai acuan bagi peneliti lainnya dalam melakukan penelitian selanjutnya.

\section{DAFTAR PUSTAKA}

Anggeaeni, Anastasia Dewi. 2017. Kompetennsi Kepribadian Guru Membentuk Kemandirian Anak Usia Dini. Jurnal Pendidikan Anak Vol. 3 No.2.

Chaer, Abdul \& Leonie Agustina. 2010. Sosiolinguistik Perkenalan Awal. Jakarta:

PT Rineka Cipta.

Hasibuan, J .J \& Moedjiono, 2012. Proses Belajar Mengajar. Bandung: PT Remaja Rosdakarya.

Lestari, Siti Rokhmi dan Eva Dwi Kurniawan. 2011. Bahasa Indonesia Untuk Perguruan Tinggi Mata Kuliah Pengembangan

Kepribadian. Yogyakarta: Edukasi Pustaka.

Mahayana, Mamayan S. 2015. Bahasa Indonesia Kreatif (Edisi Revisi). Jakarta: Penaku.

Muhammad. 2016. Metode Penelitian Bahasa. Jogyakarta: AR-Ruzz Media.

Putrayasa, Ida Bagus. 2014. Pragmatik. Yogyakarta: Graha Ilmu.

Rachmawati, Yeni dan Euis Kurniawati. 2011. Strategi Pegembangan Kreatifitas Pada Anak Usia Taman Kanak-Kanak. Jakarta: Kencana Pranada Media Group. 
Sarnia, 2015. Polisemi Dalam Bahasa Muna.Jurnal Humanika No. 15. Vol. 3. ISSN 1979-8296.

Sugihastuti. 2014. Bahasa Laporan Penelitian. Yogyakarta: Pustaka Pelajar.

Sukmadinata, Nana Syaodih. 2016. Landasan Psikologi Proses Pendidikan. Bandung: PT Remaja Rosdakarya Offset.

Sukmawati. 2006. Sistem Sapaan Bahasa Muna. Kendari: Kantor Bahasa Provinsi Sulawesi Tenggara.

Sulastri, dkk, 2014. Antologi Hasil Penelitian Bahasa dan Sastra. Jambi: Kantor Bahasa Provinsi Jambi.

Tarigan, Henry Guntur. 1990. Pengajaran Pragmatik. Bandung: Angkasa.

Yule, George. 2014. Pragmatik. Yogyakarta: Pustaka Pelajar.

Yus, Anita. 2011. Penilaian Perkembangan Belajar Anak Taman Kanak-Kanak. Jakarta: Kencana.

Zaim, M. 2014. Metode Penelitian Bahasa : Pendekatan Struktural. Padang: FBS UNP Pres Padang. 